\title{
Use of Diode Laser in Excising Bilateral Inverted Papilloma of Paranasal Sinuses
}

\author{
Saurabh Agarwal, Mohan Jagade, Avinash Borade, Anoop A, Rajesh Kar, Sunita Bage, \\ Shubhangi Kedar \\ Department of ENT, Grant Medical College \& Sir J.J. Hospital, Mumbai, India \\ Email: dr.saurabhagarwal@yahoo.com
}

Received June 7, 2013; revised July 8, 2013; accepted August 1, 2013

Copyright (C 2013 Saurabh Agarwal et al. This is an open access article distributed under the Creative Commons Attribution License, which permits unrestricted use, distribution, and reproduction in any medium, provided the original work is properly cited.

\begin{abstract}
The inverted papilloma is an uncommon unilateral benign unilateral tumor of the nose \& paranasal sinuses. Although a benign pathology, it is associated with aggressive local destruction and recurrence after removal and malignancy. The clinical picture presents non-specific signs and symptoms, such as unilateral nasal obstruction, anosmia and headache. Treatment is essentially surgical. This report has the objective of presenting an uncommon bilateral nasal inverted papilloma and the use of diode laser in surgical excision \& making a literature review. The uniqueness in our case was the use of diode laser in excision of inverted papilloma.
\end{abstract}

Keywords: Inverted Papilloma; Laser; Fess; Paranasal Sinuses

\section{Introduction}

WHO defines inverted papilloma as a benign epithelial tumor composed of well differentiated columnar or ciliated respiratory epithelium having variable squamous differentiation. The inverted papilloma (IP) is a rare and benign nasosinusal tumor, bearing an incidence of 0.75 to 1.5 cases per $100,000 /$ year. It comprises $0.5 \%$ to $4 \%$ of all primary nasal tumors [1-3]. $91 \%$ to $99 \%$ of the inverted papillomas are unilateral [4]. Inverted papillomas originate from the lateral wall of the nasal cavity, and they secondarily affect the maxillary, ethmoidal, frontal and sphenoid sinuses.

The common symptoms are nasal obstruction, epistaxis and headache in some patients complaining of nasal discharge, facial pain, chronic sinusitis, visual symptoms and epiphora.

Surgery is the treatment of choice of which lateral rhinotomy, medial maxillectomy, endoscopic endonasal excision or combined approach is usually used. We hereby report a rare case of bilateral inverted papilloma which was excised with the help of a diode laser. The uniqueness in our case was the use of the diode laser in the excision which helped us to attain a bloodless field during excision with minimal intra operative bleeding.

\section{Case Report}

A 40 years old, male patient presented with chief complaints of blocking sensation through both nostrils for 4 years. It was associated with recurrent headache, recurrent attacks of cold \& sneezing. Patient was operated twice elsewhere at peripheral hospital but symptoms recurred again. He gave history of addiction to cigarette smoking for 20 years. On anterior rhinoscopy examination, a reddish, nonglistening, polypoidal mass was seen filling both nostrils. Maxillary \& frontal sinus tenderness was present bilaterally. On diagnostic nasal endoscopy, reddish polypoidal mass was seen around middle meatus in both nostrils.

On CT Paranasal sinuses lobulated enhancing soft tissue mass was seen involving right frontal \& adjacent part of right ethmoid, left frontal, left anterior ethmoid \& bilateral superior nasal cavities \&right maxillary ostium (Figure 1). Endoscopic guided biopsy from both nostrils was suggestive of inverted papilloma. Patient was planned for excision of papilloma under general anaesthesia (Figure 2). Right sided Lateral rhinotomy incision was taken. Right medial maxillectomy was done \& nasal mass was excised with diode laser in toto (Figure 3). Left sided mass was excised endoscopically. 


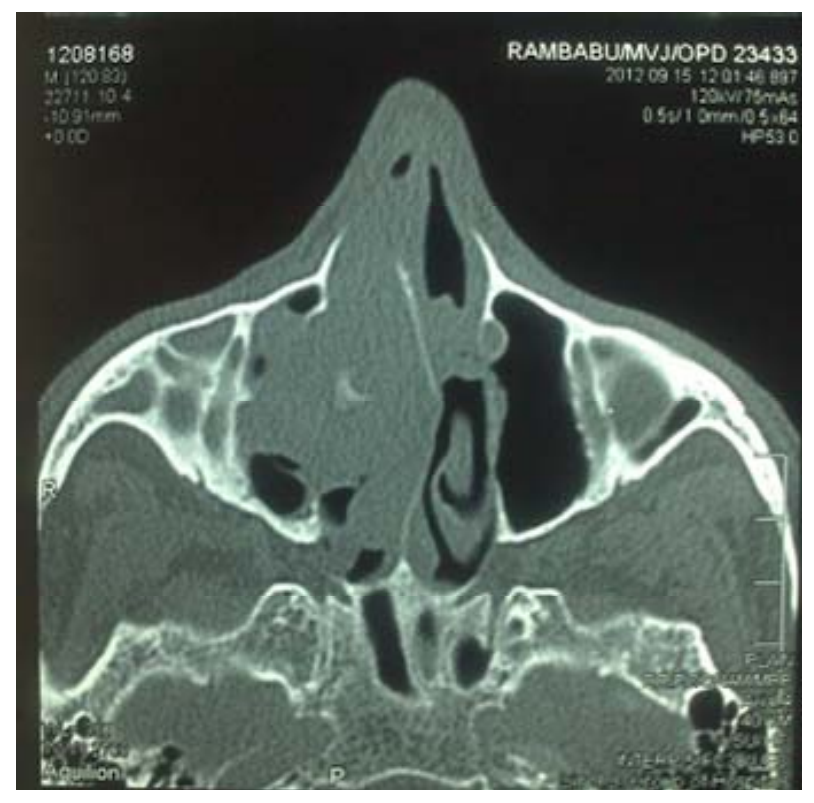

Figure 1. Axial CT PNS showing mass in both nostrils.

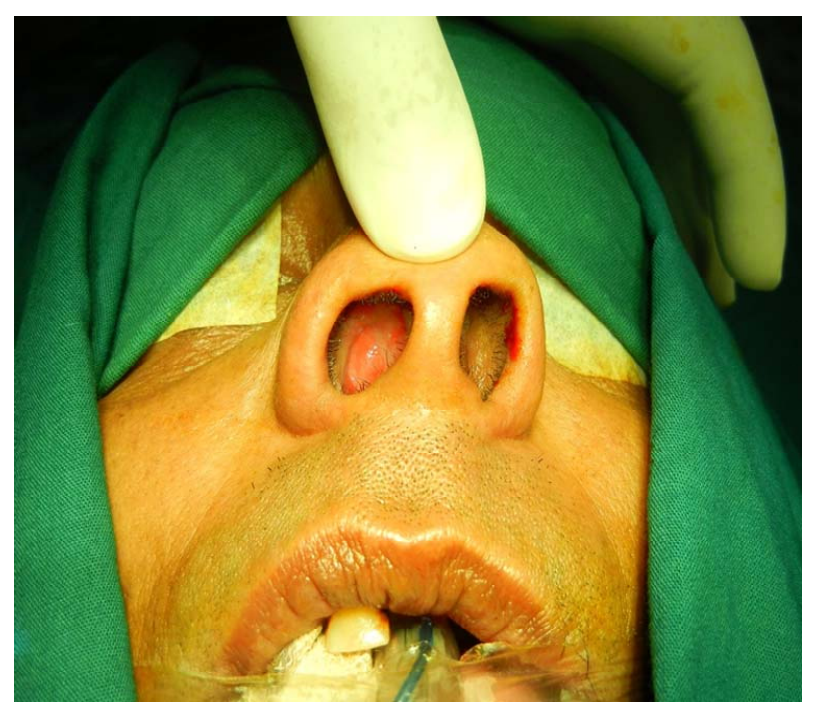

Figure 2. Pre-op photograph showing nasal mass.

His postoperative period was uneventful and histopathological examination was confirmatory of inverted papilloma. Patient was followed up for 1 year with no signs of disease recurrence.

\section{Discussion}

Inverted papilloma of the nose and paranasal sinuses is a rare tumor of the head and neck region. Inverted papilloma remains still poorly understood because of the high recurrence rate and the association with carcinoma. The mean age of the patients was between 52 and 59 years with significantly higher incidence in males (male to female ratio about $4: 1$ to $3: 1$ ) [5-7] with greater prevalence in Caucasians. Although benign, the inverted papil-

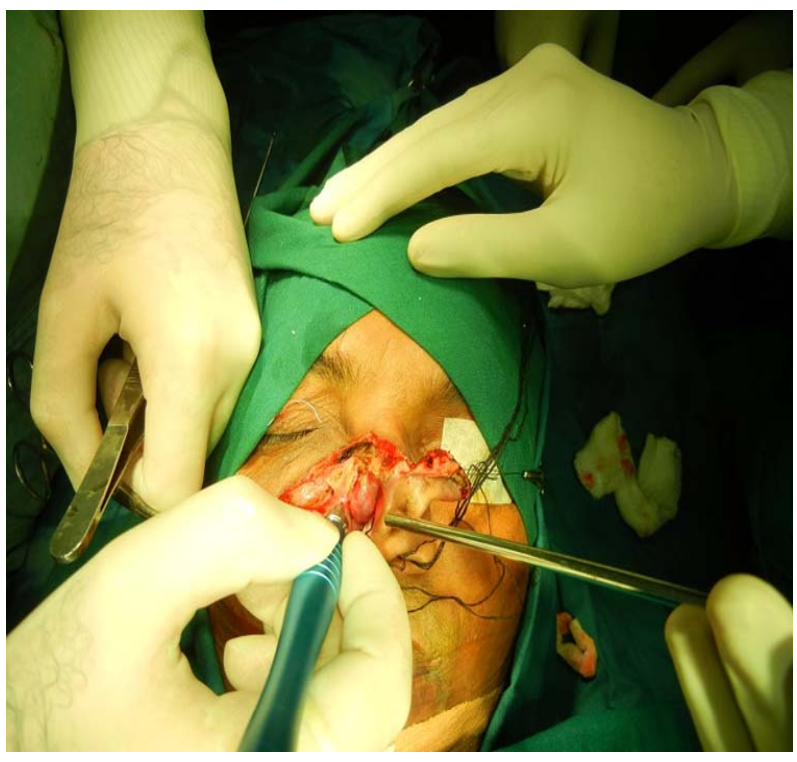

Figure 3. Inta-op photograph showing excision of mass with diode laser.

loma is characterized by an aggressive growth, great invasion potential $[4,8,9]$, being multicentric (12\%), high recurrence rates [1-3] and malignization (2\% to $53 \%$ ). About $10 \%$ of the IP cases with cellular atypia are associated with squamous cells carcinoma [3,10-13]. IP originate from the lateral wall of nasal cavity. The primary involvement of the paranasal sinuses is extremely rare, happening only to $5 \%$ of the cases [11-13].

Inverted papilloma has many synonyms such as schneiderian pailloma, transitional cell papillloma, villiform papilloma, cylindrical cell papillloma. The first description of this entity was by Ward who described the macroscopic aspect of a papillomatous neoplasm [14]. It was named schneiderian papilloma in honour of Sir. C. Victor Schneider who in the 1600s identified nasal mucosa origin from ectoderm [15]. Ringertz coined the term inverted papilloma revealing the tendency to invert into the underlying stroma [16].

The main theory on IP etiology proposes that Schneider membrane, which forms the nasosinusal tract mucosa, originates from the ectodermal invasion of the olfactory placoid. This membrane would then suffer a number of structural changes, causing a greater predisposition for neoplastic differentiation $[3,17]$.

The typical histopathological feature is inversion of the multilayer epithelium into the underlying oedematous stroma. Squamous cell epithelium is frequently found, but there is also transitional cell epithelium, cylinder cell epithelium, or combinations of these. The basement membrane is typically intact. Stroma is well vascularized and infiltrated with lymphocytes and plasma cells [18].

The commonest symptom of sinonasal inverted papilloma is progressive unilateral nasal obstruction. Other 
symptoms include blood mixed nasal discharge, headache, facial pain, frequent clearing of throat, decreased or loss of smell, epiphora or symptoms suggestive of sinusitis. Inverted papilloma generally occurs unilateral, but the bilateral involvement of the sinonasal tract has been reported in less than $1 \%$ to $9 \%$ patients [19-21].

The diagnosis must start by a detailed examination, investigating environmental exposure, noxious habits, allergies and associated diseases, and by complete otorhinolaryngological exam. Endoscopic evaluation and radiological (CT and MRI) examinations are required for tumor study and diagnosis. Biopsy together with histopathology establishes the diagnosis. A unilateral mass within the nasal cavity or paranasal sinuses with a surface configuration that appears lobulated on CT is a new sign that strongly suggests inverted papilloma as a primary diagnosis and also suggests inverted papilloma in patients with tumor recurrence.

A columnar pattern is a reliable MRI indicator of IP and reflects its histological architecture (positive predictive value of $95.8 \%$ ). The combination of this finding with the absence of extended bone erosion allows for the confident discrimination of IPs from malignant tumours [22].

Complete surgical removal is the first option for the treatment of IP and is superior to radiation or chemotherapy $[23,24]$. Lateral rhinotomy has been regarded as the traditional standard surgical approach to control IP and to avoid recurrence [25]. It gives a good overview and wide access to the surgical field and can also be performed bilaterally [26]. Alternative techniques are the midface degloving procedure \& Denker's approach. The most recent developments in surgery are minimally invasive transnasal endoscopic techniques [27,28]. In endoscopically accessible locations, recurrence rates for endoscopic vs. open surgery were similar [29]. However, other studies reported higher recurrence rates of IP [30], particularly in cases of peripheral extension, especially into the maxillary sinus [31].

In our case lateral rhinotomy approach was used. The diode laser was used for dissecting out the tumor from its attachment along with the mucosa. Under direct vision, the attachment was ablated with the laser in the cutting and coagulation modes, and the tumor was then delivered. The unique feature of our management was the use of the diode laser. Inverted papillomas are notorious for extensive bleeding, so a bloodless field was a great advantage. The hemostatic property of the dode laser helped us to achieve an almost bloodless field. This in turn helped us visualize the exact site of tumor attachment. Laser was essentially used in all three modes: contact, near-contact, and noncontact to achieve cutting, vaporization and coagulation. The diode laser's lesser depth of tissue penetration and its capability to be used in contact, near con- tact \& non contact settings allows the laser to be safely used near the lamina papyracea and skull base. So for bilateral inverted papillomas limited to the nose and paranasal sinuses, we believe our approach is a good option in view of the low rates of intra operative blood loss \& minimal post operative morbidity.

\section{Conclusion}

Inverted papillomas are known for excessive bleeding during tumour removal. The use of the diode laser in the excision of inverted papillomas helps to achieve clear intra operative field with no post operative blood transfusion requirement.

\section{REFERENCES}

[1] D. P. Vrabec, “The Inverted Schneiderian Papilloma: 25Year Study,” Laryngoscope, Vol. 104, No. 5, 1994, pp. 582-608. http://dx.doi.org/10.1002/lary.5541040513

[2] T. T. Tsue, J. W. Bailet, D. W. Barlow and K. H. Makielski, "Bilateral Sinusal Papilloma in Aplasic Maxilar Sinuses,” American Journal of Otolaryngology, Vol. 118, No. 4, 1997, pp. 263-268.

[3] M. C. Weissler, W. W. Montgomery and S. K. Montgomery, "Inverted Papiloma," The Annals of Otology, Rhinology, and Laryngology, Vol. 95, 1986, pp. 215-221.

[4] K. Oikawa, Y. Furuta, N. Oridate, T. Nagahashi, A. Homma, T. Ryu and S. Fukuda, "Preoperative Staging of Sinonasal Inverted Papilloma by Magnetic Resonance Imaging," Laryngoscope, Vol. 133, No. 11, 2003, pp. 1983-1987.

[5] M. M. Lesperance and M. E. Ramon, "Squamous Cell Carcinoma Arising in Inverted Papilloma,” Laryngoscope, Vol. 105, No. 2, 1995, pp. 178-183.

http://dx.doi.org/10.1288/00005537-199502000-00013

[6] E. Raveh, R. Feinmesser, T. Shpitzer, E. Yaniv and K. Segal, Israel Journal of Medical Sciences, Vol. 32, 1996, p. 1162.

[7] D. P. Vrabec, "The Inverted Schneiderian Papilloma: A 25-Year Study,” Laryngoscope, Vol. 104, No. 5, 1994, pp. 502-605. http://dx.doi.org/10.1002/lary.5541040513

[8] L. Segal, E. Atar and C. Mor, "Inverted Papilloma of the Nose and Paranasalsinuses,” Laryngoscope, Vol. 96, No. 4, 1996, pp. 394-398.

[9] J. A. Stankiewicz and S. J. Girs, "Endoscopic Surgical Treatment of Nasal and Paranasal Sinus Inverted Papilloma,” Otolaryngology_Head and Neck Surgery, Vol. 109, No. 6, 1993, pp. 988-995.

[10] A. C. M. Alegre, A. H. C. Ramos, R. L. Voegels and F. Romano, "Papiloma e Papilomainvertido,” In: C. A. Campos and H. O. O. Costa, Eds., Tratado de Otorrinolaringologia, Roca, São Paulo, 2003, pp. 126-132.

[11] J. H. Krouse, "Development of a Staging System for Inverted Papilloma,” Laryngoscope, Vol. 110, No. 6, 2000, pp. 965-968.

http://dx.doi.org/10.1097/00005537-200006000-00015

[12] D. P. Vrabec, “The Inverted Schneiderian Papilloma: A 
Clinical and Pathological Study,” Laryngoscope, Vol. 85, No. 1, 1975, pp. 186-221. http://dx.doi.org/10.1288/00005537-197501000-00014

[13] E. N. Myers, J. L. Fernau and J. T. Johnson, "Management of Inverted Papilloma,” Laryngoscope, Vol. 100, No. 5, 1990, pp. 481-490. http://dx.doi.org/10.1288/00005537-199005000-00008

[14] R. Kramer and M. L. Som, "True Papilloma of the Nasal Cavity,” Acta Oto-Laryngologica, Vol. 22, No. 1, 1935, pp. 22-43.

http://dx.doi.org/10.1001/archotol.1935.00640030033003

[15] N. Ringertz, "Pathology of Malignant Tumors Arising in Nasal and Paranasal Cavities and Maxilla,” Acta OtoLaryngologica, Vol. 27, 1938, pp. 31-42.

[16] R. A. Gaito, W. H. Gaylord and D. A. Hilding, "Ultrastructure of a Human Nasal Papilloma," Laryngoscope, Vol. 75, No. 1, 1965, pp. 144-152. http://dx.doi.org/10.1288/00005537-196501000-00016

[17] V. J. Hyams, "Papillomas of the Nasal Cavity and Paranasal Sinuses," Annals of Otology, Rhinology and Laryngology, Vol. 80, No. 2, 1971, pp. 192-206.

[18] C. de Flippis, G. Marioni, A. Tregnaghi, F. Marino, E. Gario and A. Staffieri, "Primary Inverted Papilloma of the Middle Ear and Mastoid,” Otology \& Neurotology, Vol. 23, No. 4, 2002, pp. 555-559. http://dx.doi.org/10.1097/00129492-200207000-00027

[19] P. P. Philips, Ro Gustafson and G. W. Facer, "The Central Behaviour of Inverted Papilloma of the Nose and Paranasal Sinuses: Report of 112 Cases \& Review of the Literature,” Laryngoscope, Vol. 100, 1990, pp. 463-469.

[20] J. Yiotaki, A. Hantzakos, D. Kandiloros and E. Ferekidis, "A Rare Location of Bilateral Inverted Papilloma of the Nose and Paranasal Sinuses,” Rhinology, Vol. 40, No. 4, 2002, pp. 220-222.

[21] V. Visvanathan, H. Wallace and P. Chumas, “An Unusual Presentation of Inverted Papilloma Case Report \& Literature Review," Journal of Laryngology and Otology, Vol. 124, No. 1, 2010, pp. 1-4. http://dx.doi.org/10.1017/S0022215109990703

[22] R. Maroldi, D. Farina, L. Palvaini, D. Lombardi, D. Tomenzoli and D. Nicolai, Magnetic Resonance, Vol. 18, No. 5, 2004, pp. 305-310.

[23] U. Ganzer, K. Donath and R. Schmelzle, "Geschwulste der Inneren Nase, der Nasennebenhohlen, des Ober- und Unterkiefers,” In: H. H. Naumann, J. Helms, C. Herberhold and E. Kastenbauer, Eds., Oto-Rhino-Laryngologie in Klinik und Praxis, Vol. 2, Thieme, Stuttgart, New York, 1992, pp. 312-359.

[24] V. J. Lund, "Optimum Management of Inverted Papilloma,” Journal of Laryngology \& Otology, Vol. 114, No. 11, 2000, pp. 194-197.

[25] E. N. Myers, V. L. Schramm and E. L. Barnes, "Management of Inverted Papilloma of the Nose and Paranasal Sinuses,” Laryngoscope, Vol. 91, No. 12, 1981, pp. 20712084. http://dx.doi.org/10.1288/00005537-198112000-00009

[26] S. A. Hosal and J. L. Freeman, "Bilateral Lateral Rhinotomy for Resection of Bilateral Inverted Papilloma," Otolaryngology—Head and Neck Surgery, Vol. 114, No. 1, 1996, pp. 103-105. http://dx.doi.org/10.1016/S0194-5998(96)70292-9

[27] M. Winter, R. A. Rauer, U. Gode, G. Waitz and M. E. Wigand, "Invertierte Papillome der Nase und ihrer Nebenhohlen. Langzeitergebnisse Nach Endoskopischer Endonasaler Resektion,” HNO, Vol. 48, No. 8, 2000, pp. 568-572. http://dx.doi.org/10.1007/s001060050618

[28] P. J. Wormald, E. Ooi, C. A. van Hasselt and S. Nair, "Endoscopic Removal of Sinonasal Inverted Papilloma Including Endoscopic Medialmaxillectomy," Laryngoscope, Vol. 113, No. 5, 2003, pp. 867-873. http://dx.doi.org/10.1097/00005537-200305000-00017

[29] T. Klimek, E. Atai, M. Schubert and H. Glanz, "Inverted Papilloma of the Nasal Cavity and Paranasal Sinuses: Clinical Data, Surgicalstrategy and Recurrence Rates," Acta Oto-Laryngologica, Vol. 120, No. 2, 2000, pp. 267-272. http://dx.doi.org/10.1080/000164800750001071

[30] P. P. Phillips, R. O. Gustafson and G. W. Facer, “The Clinical Behavior of Inverting Papilloma of the Nose and Paranasal Sinuses: Report of 112 Cases and Review of the Literature,” Laryngoscope, Vol. 100, No. 5, 1990, pp. 463-469. http://dx.doi.org/10.1288/00005537-199005000-00004

[31] C. Zumegen, J. P. Thomas and O. Michel, "Erfahrungen mit der Endonasalen Endoskopischen Operation des Invertierten Papilloms der Nase und Nasenebenhohlen," Laryngorhinootologie, Vol. 79, No. 4, 2000, pp. 221-225. http://dx.doi.org/10.1055/s-2000-8991 